\title{
Studies on the Effect of Hot Water Treatment on Shelf Life of Custard Apple Stored at Low Temperature $\left(13^{\circ} \mathrm{C} \pm 1\right)$ on $\mathrm{cv}$. Balanagar
}

\author{
G. Shailaja ${ }^{1 *}$, A. Kiran Kumar ${ }^{2}$ and A. Mamatha ${ }^{3}$ \\ ${ }^{1}$ Sri Konda Laxman Telangana State Horticultural University, Fruit Research station, \\ Sangareddy-502 001, India \\ ${ }^{2}$ College of Horticulture, Rajendra nagar, Hyderabad-500030, Telangana, India \\ ${ }^{3}$ Vegetable Research Station, Rajendra nagar, Hyderabad-500030, Telangana, India \\ *Corresponding author
}

\section{A B S T R A C T}

\begin{tabular}{|c|}
\hline Keywords \\
\hline $\begin{array}{l}\text { Balanagar, Physiological } \\
\text { loss in weight }(\%) \text {, } \\
\text { Firmness }\left(\mathrm{kg} \mathrm{cm}^{-2}\right) \text {, } \\
\text { Ripening }(\%), \text { Hot water } \\
\text { chamber }\end{array}$ \\
\hline Article Info \\
\hline $\begin{array}{l}\text { Accepted: } \\
04 \text { November } 2018 \\
\text { Available Online: } \\
10 \text { December } 2018\end{array}$ \\
\hline
\end{tabular}

\section{Introduction}

Annona squamosa L., also called sugar apple, sweetsop or custard apple, is listed as one of the world's five most famous tropical fruits. Custard apple is native to the tropical America, which is commercially cultivated in tropical and sub-tropical regions of Australia.

Custard apple is one of the important fruit crops of Andhra Pradesh. Nearly 75000 tons of this fruit is available from the state 2, 3 . Custard apple, popularly known as Sitaphal is
A laboratory experimental study was conducted on studies on the effect of hot water treatment on shelf life of custard apple stored at low temperature $\left(13^{\circ} \mathrm{C} \pm 1\right)$ on $\mathrm{cv}$. balanagar" at Department of Horticulture, Fruit Research Station Sangareddy and framed in Factorial Completely Randomized design. Unblemished, mature fruits of custard apple $\mathrm{cv}$. Balanagar of uniform size were directly picked from custard apple orchard and washed thoroughly in running tap water to remove the adherent dirt material. The hot water treatments were done with the help of hot water chamber. The machine washed with tap with water, in the middle of the chamber the iron mesh was placed. The washed fruits were placed on the mesh, the water level should be maintain up to the above the fruit. The fruits are placed in the plastic trays. The temperature levels should be maintained with thermostat. After the treatment the moisture on the surface of the fruits were dried and the fruits were stored at low temperature. Indicating the delayed ripening and hence increasing the storage /shelf life of the fruits. 
minimum inputs (Rajput, 1985). The steady increase in area under custard apple has enhanced the fruit flow into the markets which most of the time leads to glut in the markets (Jalikop, 2006). The practices reported by (Salunkhe and Kadam, 1995) and Reddy (2000) suggest that the fruits of custard apple after harvesting are either loaded directly or packed in bamboo baskets with paddy straw or leaves of custard apple as cushioning material and transported to markets. Modified atmosphere packaging (MAP) is intended to create an appropriate gaseous atmosphere around a commodity packed in film packages to enhance shelf life and conserve the quality of packed produce (Deepak Raj Rai et al., 2002).

Custard apple, one of the delicious and nutritionally valuable fruit meant for table purpose has a soft granular, juicy and sugary pulp with mild flavour and slight acidity (Kumar et al., 2011). The shelf life of the custard apple is very short (Chadha, 2006) due to the climacteric nature of the fruit. Therefore, it is sold in local markets only. To utilize the large quantity of fruit produced during glut period, different researchers had reported the use of custard apple in preparation of juice, ice creams, milk shakes, soft drink and alcoholic beverages, i.e. wine (Jagtap and Bapat, 2014; Kumar et al., 2011; Luciana et al., 2010).

\section{Materials and Methods}

In the present investigation, tried the hot water treatment for cv. Balanagar and. Lab Experiment was laid in Factorial Completely Randomized Design. In each treatment 6 units containing 4 fruits were tested and observations were recorded at 4 days interval for Physiological loss in weight, Firmness (kg $\mathrm{cm}^{-2}$ ), Ripening (\%) Statistical analysis was carried out in Windostat 8.5

\section{Factor -1}

\section{Temperature}

$\mathrm{F}_{1}$ - Dipping of fruits in hot water at $45^{\circ} \mathrm{C}$

$\mathrm{F}_{2}$ - Dipping of fruits in hot water at $50^{\circ} \mathrm{C}$

$\mathrm{F}_{3}$ - Dipping of fruits in hot water at $55^{\circ} \mathrm{C}$

\section{Factor -2}

\section{Time}

$\mathrm{D}_{1^{-}}$Dipping of fruits in hot water for 5 minutes

$\mathrm{D}_{2^{-}}$Dipping of fruits in hot water for 10 minutes

$\mathrm{D}_{3^{-}}$Dipping of fruits in hot water for 15 minutes

$\mathrm{D}_{4^{-}}$Dipping of fruits in hot water for 20 minutes

\section{Treatment combinations}

$\mathrm{F}_{1} \mathrm{D}_{1} \quad \mathrm{~F}_{2} \mathrm{D}_{1} \quad \mathrm{~F}_{3} \mathrm{D}_{1}$

$\mathrm{F}_{1} \mathrm{D}_{2} \quad \mathrm{~F}_{2} \mathrm{D}_{2} \quad \mathrm{~F}_{3} \mathrm{D}_{2}$

$\mathrm{F}_{1} \mathrm{D}_{3} \quad \mathrm{~F}_{2} \mathrm{D}_{3} \quad \mathrm{~F}_{3} \mathrm{D}_{3}$

$\begin{array}{lll}\mathrm{F}_{1} \mathrm{D}_{4} & \mathrm{~F}_{2} \mathrm{D}_{4} & \mathrm{~F}_{3} \mathrm{D}_{4}\end{array}$

\section{Results and Discussion}

\section{Physiological loss in weight $(\%)$}

The data pertaining to physiological loss in weight (PLW) of custard apple fruits $\mathrm{cv}$. Balanagar treated with different hot water and stored at low temperature are presented in Table 1.

There were significant differences in PLW of custard apple fruits treated with hot water. Significantly lowest PLW was recorded in fruits treated with $50^{\circ} \mathrm{C}$ on $4^{\text {th }}$ day (2.36) and $8^{\text {th }}$ day of experimentation. 
Table.1 Effect of hot water treatments on physiological loss in weight (\%) of custard apple fruits cv. Balanagar at low temperature $\left(13^{\circ} \mathrm{C} \pm 1\right)$

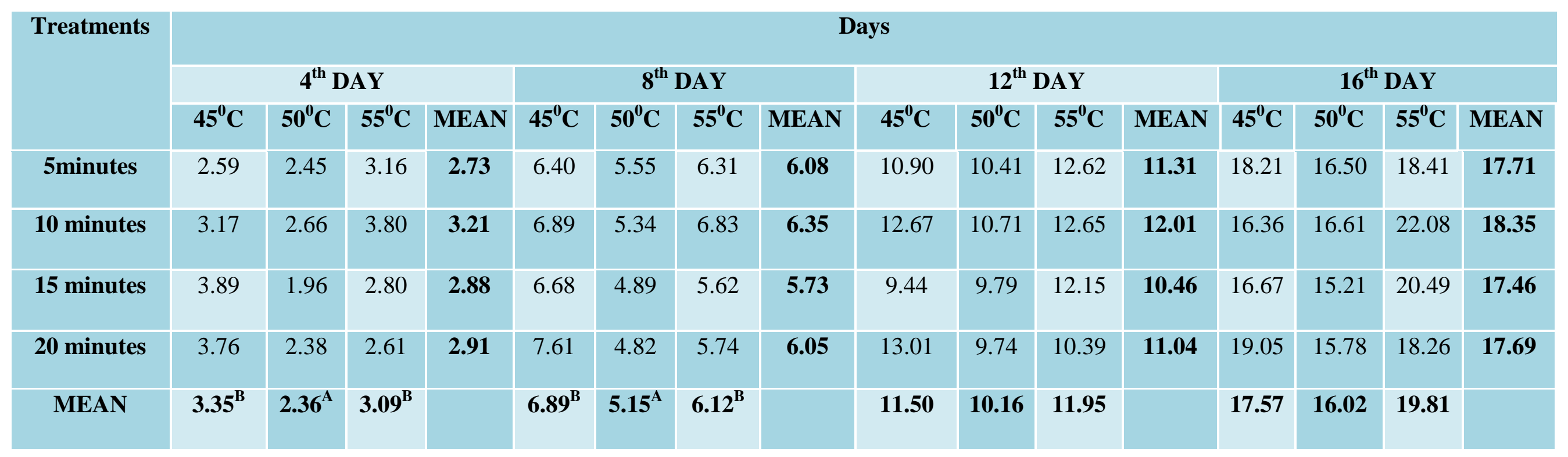

\begin{tabular}{|c|c|c|c|c|c|c|c|c|}
\hline & \multicolumn{2}{|c|}{$4^{\text {th }}$ DAY } & \multicolumn{2}{|c|}{$8^{\text {th }}$ DAY } & \multicolumn{2}{|c|}{$12^{\text {th }}$ DAY } & \multicolumn{2}{|c|}{$16^{\text {th }}$ DAY } \\
\hline & CD at (0.05) & S.Em \pm & CD at (0.05) & S.Em \pm & CD at (0.05) & S.Em \pm & CD at (0.05) & S.Em \pm \\
\hline Factor A (Temperature) & 0.43 & 0.15 & 0.83 & 0.28 & N.S & 0.85 & N.S & 1.25 \\
\hline Factor B (Time) & N.S & 0.17 & N.S & 0.33 & N.S & 0.98 & N.S & 1.45 \\
\hline For $\mathbf{A} \times \mathbf{B}$ & 0.87 & 0.30 & N.S & 0.57 & N.S & 1.71 & N.S & 2.51 \\
\hline
\end{tabular}


Table.2 Effect of hot water treatments on firmness $\left(\mathrm{kg} \mathrm{cm}^{-2}\right)$ of custard apple fruits $\mathrm{cv}$. Balanagar at low temperature $\left(13^{\circ} \mathrm{C} \pm 1\right)$

\begin{tabular}{|c|c|c|c|c|c|c|c|c|c|c|c|c|c|c|c|c|}
\hline \multirow[t]{3}{*}{ Treatments } & \multicolumn{16}{|c|}{ Days } \\
\hline & \multicolumn{4}{|c|}{0 DAY } & \multicolumn{4}{|c|}{$4^{\text {th }}$ DAY } & \multicolumn{4}{|c|}{$8^{\text {th }}$ DAY } & \multicolumn{4}{|c|}{$12^{\text {th }}$ DAY } \\
\hline & $45^{\circ} \mathrm{C}$ & $50^{0} \mathrm{C}$ & $55^{\circ} \mathrm{C}$ & MEAN & $45^{\circ} \mathrm{C}$ & $50^{0} \mathrm{C}$ & $55^{\circ} \mathrm{C}$ & MEAN & $45^{\circ} \mathrm{C}$ & $50^{\circ} \mathrm{C}$ & $55^{\circ} \mathrm{C}$ & MEAN & $45^{\circ} \mathrm{C}$ & $50^{\circ} \mathrm{C}$ & $55^{\circ} \mathrm{C}$ & MEAN \\
\hline 5minutes & 10.50 & 9.50 & 9.10 & 9.70 & 8.10 & 7.20 & 6.70 & 7.33 & 5.60 & 4.96 & 3.96 & $4.84^{a}$ & 2.20 & 2.00 & 2.20 & 2.13 \\
\hline 10 minutes & 8.30 & 11.30 & 10.60 & 10.06 & 6.20 & 8.13 & 7.60 & 7.31 & 3.76 & 4.83 & 4.83 & $4.47^{b}$ & 2.00 & 2.00 & 2.00 & 2.00 \\
\hline 15 minutes & 8.50 & 10.60 & 10.20 & 9.76 & 6.50 & 7.90 & 7.60 & 7.33 & 4.26 & 5.06 & 4.86 & $4.73^{a}$ & 2.00 & 2.40 & 2.13 & 2.17 \\
\hline 20 minutes & 11.30 & 8.50 & 10.90 & 10.23 & 7.60 & 6.60 & 7.70 & 7.30 & 4.76 & 4.96 & 4.96 & $4.90^{\mathrm{a}}$ & 2.10 & 2.50 & 1.80 & 2.13 \\
\hline MEAN & 9.65 & 9.97 & 10.20 & & 7.10 & 7.45 & 7.40 & & $4.60^{A}$ & $4.95^{B}$ & $4.65^{A}$ & & 2.07 & 2.22 & 2.03 & \\
\hline
\end{tabular}

\begin{tabular}{|c|c|c|c|c|c|c|c|c|}
\hline & \multicolumn{2}{|c|}{0 DAY } & \multicolumn{2}{|c|}{$4^{\text {th }}$ DAY } & \multicolumn{2}{|c|}{$8^{\text {th }}$ DAY } & \multicolumn{2}{|c|}{$12^{\text {th }}$ DAY } \\
\hline & CD at (0.05) & S.Em \pm & CD at (0.05) & S.Em \pm & CD at (0.05) & S.Em \pm & CD at (0.05) & S.Em \pm \\
\hline Factor A (Temperature) & N.S & 0.21 & N.S & 0.16 & 0.18 & 0.06 & N.S & 0.05 \\
\hline Factor B (Time) & N.S & 0.24 & N.S & 0.18 & 0.21 & 0.07 & N.S & 0.06 \\
\hline For $\mathbf{A} \times \mathbf{B}$ & 1.23 & 0.42 & 0.66 & 0.32 & 0.37 & 0.12 & 0.34 & 0.11 \\
\hline
\end{tabular}


Table.3 Effect of hot water treatments on ripening (\%) of custard apple fruits cv. Balanagar at low temperature $\left(13^{\circ} \mathrm{C} \pm 1\right)$

\begin{tabular}{|c|c|c|c|c|c|c|c|c|c|c|c|c|}
\hline \multirow[t]{3}{*}{ Treatments } & \multicolumn{12}{|c|}{ Days } \\
\hline & \multicolumn{4}{|c|}{$4^{\text {th }}$ DAY } & \multicolumn{4}{|c|}{$8^{\text {th }}$ DAY } & \multicolumn{4}{|c|}{$12^{\text {th }}$ DAY } \\
\hline & $45^{\circ} \mathrm{C}$ & $50^{0} \mathrm{C}$ & $55^{0} \mathrm{C}$ & MEAN & $45^{\circ} \mathrm{C}$ & $50^{0} \mathrm{C}$ & $55^{0} \mathrm{C}$ & MEAN & $45^{\circ} \mathrm{C}$ & $50^{\circ} \mathrm{C}$ & $55^{0} \mathrm{C}$ & MEAN \\
\hline 5minutes & 16.66 & 10.00 & 10.00 & $12.22^{\mathrm{a}}$ & 36.66 & 40.00 & 30.00 & $35.55^{\mathrm{a}}$ & 60.00 & 56.66 & 60.00 & $58.88^{a}$ \\
\hline 10 minutes & 6.70 & 6.70 & 6.70 & $6.70^{b}$ & 36.70 & 30.00 & 20.00 & $28.90^{b}$ & 60.00 & 60.00 & 50.00 & $56.66^{\mathrm{a}}$ \\
\hline 15 minutes & 6.70 & 10.00 & 0.00 & $5.56^{b}$ & 30.00 & 24.43 & 20.00 & $24.81^{c}$ & 66.66 & 50.00 & 46.66 & $54.44^{b}$ \\
\hline 20 minutes & 6.70 & 6.66 & 6.66 & $6.67^{b}$ & 33.33 & 27.76 & 16.66 & $25.92^{b}$ & 63.33 & 53.33 & 43.33 & $53.33^{b}$ \\
\hline MEAN & $9.19^{B}$ & $8.34^{B}$ & $5.84^{\mathrm{A}}$ & & $34.17^{C}$ & $30.55^{B}$ & $21.66^{\mathrm{A}}$ & & $62.50^{\mathrm{C}}$ & $55.00^{B}$ & $50.00^{A}$ & \\
\hline
\end{tabular}

\begin{tabular}{|l|c|c|c|c|c|c|}
\hline & \multicolumn{3}{|c|}{$4^{\text {th }}$ DAY } & \multicolumn{2}{|c|}{$8^{\text {th }}$ DAY } & S.Em \pm \\
\hline & CD at (0.05) & S.Em \pm & CD at (0.05) & S.Em at (0.05) \\
\hline Factor A (Temperature) & 1.81 & 0.62 & 2.87 & 0.98 & 3.43 \\
\hline Factor B (Time) & 2.09 & 0.71 & 3.32 & 1.13 & 3.96 \\
\hline For A x B & 3.62 & 1.24 & N.S & 1.97 & 6.87 \\
\hline
\end{tabular}


Significantly higher PLW was recorded with $45^{\circ} \mathrm{C}$ treated fruits on $4^{\text {th }}$ day $(3.35)$ and $8^{\text {th }}$ day (6.89) of storage. The PLW on $12^{\text {th }}$ day and $16^{\text {th }}$ day of storage were not significant. The treatment, dipping time in hot water has no significant effect on PLW of custard apple fruits.

The interaction between temperature and dipping times on PLW of custard apple fruits was significant on $4^{\text {th }}$ day. The rest of the treatment combinations were non-significant. Lowest PLW was recorded on $4^{\text {th }}$ day at $50^{\circ} \mathrm{C}$ for 15 minutes of dipping time (1.96). Significantly highest PLW was recorded with the treatment combination on $4^{\text {th }}$ day with $45^{0}$ Cfor 15 minutes (3.89).

\section{Firmness $\left(\mathrm{kg} \mathrm{cm}^{-2}\right)$}

The results observed on firmness of custard apple fruits cv. Balanagar treated with different hot water and stored at low temperature are presented in Table 2 .

There was significant difference in firmness of custard apple fruits treated with hot water on $8^{\text {th }}$ day of storage. The rest of the treatments were non-significant. Significantly higher firmness was recorded with $50^{\circ} \mathrm{C}$ treated fruits on $8^{\text {th }}$ day of storage (4.95). Significantly lowest firmness was recorded in fruits treated with $45^{\circ} \mathrm{C}$ on $8^{\text {th }}$ day of storage (4.60), which is on par with $55^{\circ} \mathrm{C}$ on $8^{\text {th }}$ day of storage (4.65).

The treatment, dipping time in hot water has significant effect on firmness of custard apple fruits on $8^{\text {th }}$ day of storage. The rest of the treatments were non-significant. Significantly higher firmness was recorded with 20 minutes dipped fruits on $8^{\text {th }}$ day of storage (4.84), which is on par with 5 minutes (4.84), and 15 minutes (4.73). Significantly lower firmness was recorded with 10 minutes dipped fruits on $8^{\text {th }}$ day of storage (4.47).
The interaction between temperature and dipping times on firmness of custard apple fruits was significant. Significantly highest firmness was recorded with the treatment combination on ' 0 ' day with $50^{\circ} \mathrm{C}$ for 10 minutes (11.30). Significantly lowest firmness was recorded on $12^{\text {th }}$ day at $55^{\circ} \mathrm{C}$ for 20 minutes of dipping time (1.80).

\section{Ripening (\%)}

The data pertaining to ripening of custard apple fruits cv. Balanagar treated with different hot water and stored at low temperature are presented in Table 3 .

There were significant differences in ripening of custard apple fruits treated with hot water. Significantly lowest ripening was recorded in fruits treated with $55^{\circ} \mathrm{C}$ on $16^{\text {th }}$ day of storage (50.00). Significantly higher ripening was recorded with $45^{0} \mathrm{C}$ treated fruits on $16^{\text {th }}$ day of storage (50.00).

There was significant difference in ripening of custard apple fruits among the dipping times. Significantly lower ripening was recorded with 5 minutes dipped fruits on $16^{\text {th }}$ day of storage (58.88). Significantly lower ripening was recorded with 20 minutes dipped fruits on $16^{\text {th }}$ day of storage (53.33), which is on par with 15 minutes dipped fruits on $16^{\text {th }}$ day of storage (54.44).

The interaction between temperature and dipping times on ripening of custard apple fruits was significant. Significantly lowest ripening was recorded with the treatment combination of $55^{\circ} \mathrm{C}$ for 20 minutes of dipping time on $12^{\text {th }}$ day (1.80) and on $16^{\text {th }}$ day of storage.

Significantly highest ripening was recorded with the treatment combination of $45^{\circ} \mathrm{C}$ for 20 minutes of dipping time on $16^{\text {th }}$ day of storage (63.33). 


\section{References}

Chadha, K. L. 2006. Handbook of horticulture. New Delhi: ICAR, pp. 109-114.

Deepak Raj Rai, Harinder Singh Oberoi, and Bangali Baboo, 2002. Modified atmosphere Packaging and its effect on quality and shelf life of fruits and vegetables-An over view. J. of Food Sci. Technol. 39: 199-207

Jagtap, U. B., and Bapat, V. A. 2014. Phenolic composition and antioxidant capacity of wine prepared from custard apple (Annona squamosa L.) fruits. Journal of Food Processing and Preservation.

Jalikop, S. H. 2006. Custard apple, In: Hand book of Horticulture. (Ed. Chadha K L,) ICAR pub, New Delhi, India, pp 109114.

Kumar, V., Goud, V., Babu, J. D., \& Reddy, R. S. 2011. Preparation and evaluation of custard apple wine: Effect of dilutions on physico-chemical and sensory quality characteristics. International Journal of Food and Fermentation, 255-260.

Luciana, A. R., Santos, L., Lúcia, P. S. P., \& Maria Amélia, D. 2010. Boaventura acetogenins from Annona cornifolia and their antioxidant capacity. Food Chemistry, 122, 1129-1138.

Rajput, C. B. S. 1985. Custard apple, In: Fruits of India-Tropical and subtropical, (Ed. T K Bose,) Naya Prakash Pub, Calcutta, India, pp 479-486.

Salunkhe, D. K. and Kadam, S. S. 1995. Handbook of Fruit Science and Technology, Ed. Marcel Dekker, Inc., New York, pp. 81-83.

Wills, R. B. H., Mc Glasson, W. B., Graham, D., Lee, T. H. and Hall, E. G. 1996. Post-harvest - An introduction to the physiology and Handling of fruits and vegetables. C B S Publishers and Distributors, New Delhi, pp.112.

\section{How to cite this article:}

Shailaja, G., A. Kiran Kumar and Mamatha, A. 2018. Studies on the Effect of Hot Water Treatment on Shelf Life of Custard Apple Stored at Low Temperature $\left(13^{\circ} \mathrm{C} \pm 1\right)$ on cv. Balanagar. Int.J.Curr.Microbiol.App.Sci. 7(12): 84-90. doi: https://doi.org/10.20546/ijcmas.2018.712.011 